\title{
A Conversation Analysis of Repair Strategies in Indonesian Elementary EFL Students
}

\author{
Tita Novitasari, Ernie D. A. Imperiani \\ English Language and Literature Study Program \\ Universitas Pendidikan Indonesia \\ Bandung, Indonesia \\ ernie_imperiani@upi.edu
}

\begin{abstract}
This study investigated the types of repair strategies and techniques of repair initiation used by Indonesian elementary EFL students during the classroom interaction with their teacher. The participants were elementary EFL students at the beginner level. By using qualitative research, the study used four types of repair strategies by Schegloff, Jefferson, and Sacks (1977) and techniques of repair initiation from Finegan (2008). The data were taken from video recorded of classroom interactions that were transcribed by applying Jefferson Transcription Notation (2004). The findings of the study revealed that the students used all types of repair strategies. The most frequently is OISR which obtained 23 occurrences $(37.1 \%)$. Besides, the three techniques were found in the conversation. Asking questions toward the problem is the dominant one which 31 occurrences $(\mathbf{5 0 . 0 \%})$ ). Another technique was revealed which is giving a possible understanding of the problem. The results show that the speakers produced the trouble source more which affected the recipient to initiate asking for the repair, meaning that the trouble source identified by the teacher, but the students repaired. The trouble source that appeared was affected by the students' proficiency and the lack of topic knowledge. Also, the teachers initiated asking for an explanation to raise the students' ability in terms of their English knowledge and speaking fluency. However, the teacher should allow the students to repair their trouble source or problem themselves.
\end{abstract}

Keywords: Conversation Analysis, EFL students, repair strategies, repair techniques

\section{INTRODUCTION}

In recent times, the conversation has been extended into spoken discourse such as doctor-patient consultations, news interviews, talk show, and classroom interaction (Paltridge, 2006). To examine conversation, Conversation Analysis (CA) becomes a suitable approach because it is the organization of social action through talk (Mazeland, 2006). The sociologist Schegloff (1973) developed Conversation Analysis.

In a study of $\mathrm{CA}$, the phenomenon called repair is an aspect of conversational interaction and becoming a crucial thing in a conversation. Schegloff, Jefferson, and Sacks (1977) define repair as a tool used in conversation to correct an error made by speaker or trouble source and state that repair deals with recurrent problems in speaking, hearing, and understanding. There are two main types of repair strategies, namely self-repair and other-repair. Schegloff et al. (1977) explain that self-repair occurs when the speaker repairs the problem, while other-repair occurs when the recipient is the one who corrects the problem. They also describe repair can be initiated and resolved by the speaker who utters the mistake during a conversation or by the interlocutor who hears it. Therefore, Schegloff et al. (1977) propose four types of repair. First, self-initiated self-repair (SISR). It occurs when the trouble source is the speaker him/herself and he/she who repairs it. Second, other-initiated and self-repair (OISR) appears when the interlocutor causes repair completion, which is done by the speaker. Next, self-initiated and other repairs (SIOR) appears when the producer of the trouble source initiates then the interlocutor completes it. The last is otherinitiated other-repair (OIOR) happens where the interlocutor notices the problem and repairs it for the speaker.

Besides the types of repair strategies, Schegloff et al. (1977) proposed repair techniques. There are two techniques to repair initiation. First, self-initiation within the same turn use a variety of non-lexical speech perturbation such as cutoffs, sound stretches, 'uh'. The second, other-initiation use a group turn-constructional devices to initiate repair that is divided into several parts such as huh, what?, use question words who, where, when, a partial repeat of the trouble-source turn, plus a question word, a partial repeat of the troublesource turn, and the last is $\mathrm{Y}^{\prime}$ mean plus a possible understanding of prior turn.

Regarding repair analysis, there are some studies on repair strategies that have been conducted in various contexts. For example in text-based communication, (e.g., Meredith \& Stokoe, 2014; Tiara, 2018), students with autism (e.g., Ohtake, et al., 2005; Ohtake, Wehmeyer, Nakaya, Takahashi, \& Yanagihara, 2011), and classroom (e.g., Cho \& Larke, 2010; Rabab'ah, 2013). In the EFL context, some studies have been conducted, for example, Khodadady and Alifathabadi (2014) on repair in Iranian intermediate and advanced learners and Chalak and Karimi (2017) who examined turn-taking and repair strategies in Intermediate EFL learners.

\section{METHOD}

This study was qualitative because the data were conversational interaction in the classroom. Whereas, Wray, and Bloomer (2006) state that qualitative research involves more descriptions and analysis than computation.

The participants of the study were Elementary EFL students at one private Elementary School in the Northern part of Bandung. In this study, the bilingual class consisted of 10 males and 15 females with the same level ranging from 10-11 years of age were selected. 
In analyzing the repair strategies, there are two essentials terms of repair that need to be understood, namely repaired segment and repairing segment (Schegloff et al., 1977). According to them (as cited in Liddicoat, 2007), the bold clause is a repaired segment. It is as the trouble source or repairable, and the thing in the talk which needs to be repaired. Meanwhile, the repairing segment is the segment of utterance that repairs the trouble source. It also must follow the initiation $(\square)$ given by another participant. The repairing segment can be done in several ways for example by asking the question, repeating the misheard or misunderstood, or using particle and expression.

\section{FINDINGS AND DISCUSSION}

The study revealed that there are 62 occurrences of repair strategies used by EFL students that are shown and discussed below.

\section{A. The Types of Repair Strategies}

The analysis of types of repair strategies used the theory proposed by Schegloff et al. (1977). The results showed that the participants used all types of repair strategies during the conversation, which are self-initiated self-repair (SISR), selfinitiated other-repair (SIOR), other-initiated self-repair (OISR), and other-initiated other-repair (OIOR). The results of the types of repair strategies are shown in the following Table I.

TABLE I. THE TYPES OF REPAIR STRATEGIES

\begin{tabular}{|c|l|c|c|}
\hline \multirow{2}{*}{ No } & Types of Repair Strategies & Frequency & Percentage \\
\hline 1 & Self-initiated self-repair (SISR) & 15 & $24.2 \%$ \\
\hline 2 & Self-initiated other-repair (SIOR) & 8 & $12.9 \%$ \\
\hline 3 & Other-initiated self-repair (OISR) & 23 & $37.1 \%$ \\
\hline 4 & Other-initiated other-repair (OIOR) & 16 & $25.8 \%$ \\
\hline \multicolumn{2}{|c}{ Total } & $\mathbf{6 2}$ & $\mathbf{1 0 0 \%}$ \\
\hline
\end{tabular}

Table I shows that the participants used all types of repair strategies. The explanation of each type of repair strategies employed by Elementary EFL students is discussed as follows.

\section{B. Other-Initiated Self-Repair (OISR)}

According to Schegloff et al. (1977), other-initiated selfrepair (OISR) occurs when the interlocutor identifies the trouble source, and the speaker repairs it for the interlocutor. In the analysis, there are 23 occurrences $(37.1 \%)$ for this type. The example is exemplified in excerpt 2 below.

\section{Excerpt 1}

Student 1: I go to school with a motorcycle.

Teacher : Huh?

Student 2: $\square$ Bukannya went?

(Isn't it "went"?)

Teacher : $\square$ Why, why, why?

Student 2: Karena sudah:: (2.0) sudah terjadi.

(Because it's already:: (2.0) already happened.)

In this excerpt, the students here were discussing the past tense. One of the students (student 1) tried to answer the question, but the teacher and another student (student 2) identified there was a problem in the student's 1 utterance. In the conversation, when the participants are more than two, it is possible for the trouble source is initiated by more than one recipient (Tiara, 2018). Then, the teacher used the particle of "huh?" when he noticed the trouble source. Also, the student 2 initiated asking student 1 a question by saying, "bukannya went?" (isn't it went?). The teacher also immediately asked the students the reason why the answer was "went" instead of "go." The symbol $(\square)$ was the initiation for the problem. In the next turn, student 2 repaired the trouble source by answering the teacher's question and switching into Indonesian "karena sudah (2.0) sudah terjadi" (because it's already (2.0) already happened).

From the excerpt above, the teacher or the recipient acted as the initiator; it is someone who initiates the trouble source, while the student 2 or the speaker was the one who repaired the utterance. In this case, when the recipient identifies the trouble source in the speaker utterance and initiate to get a clarification or explanation toward the trouble source to the speaker, and the speaker repairs it for the interlocutor, it is called as otherinitiated self-repair (OISR) according to Schegloff et al. (1977). It means that the teacher identified the trouble source, and the student did the repair (Chalak \& Karimi, 2017). Besides, the students in the conversation answered the question by using Indonesian because he was afraid that the answer would be incorrect if he answered it using English.

\section{Other-Initiated Other-Repair (OIOR)}

There are 16 occurrences of other-initiated other-repair (OIOR). OIOR is how the trouble source is identified and repaired by the interlocutor or recipient. According to Schegloff et al. (1977), other-initiated other-repair occurs when the recipient completes the repair. In the analysis, this type appeared 16 times $(20.8 \%)$. This is an example of how this type occurred in the conversation.

\section{Excerpt 2}

Student : I fell (2.0) bicycle.

Teacher : $\square$ I fell off a bicycle.

In this excerpt, the participants were discussing the past tense. The teacher asked the students to give an example of a sentence in past tense form. In the next turn, one of the students gave an example. The trouble source appeared when the student uttered the example by saying, "I fell (2.0) bicycle." The teacher here indicated there was a trouble source in the previous turn in terms of grammar. However, the student unaware of the mistake in his utterance. Then, the teacher simultaneously initiated and repaired it into the correct one for the student by saying, "I fell off a bicycle."

The conversation among the teacher and the student above showed that the teacher initiated and repaired the student's utterance into the correct one. As Schegloff et al. (1977) state, when the interlocutor initiates and completes the trouble source, it is categorized as other-initiated other-repair. Tiara (2018) in her study states that OIOR occurs when the initiation and completion are done simultaneously. This strategy is used to correct the problem that is produced by the current speaker as well as give the correct answer. 


\section{Self-Initiated Self-Repair (SISR)}

Self-initiated self-repair (SISR) is slightly different from the occurrence of OIOR. In the analysis, SISR obtained 15 repairs (24.2\%). This type is similar to OIOR. However, SISR appears when the speakers indicate their own mistake in their utterance while conveying the message to the interlocutor. The following excerpt is an example of SISR.

\section{Excerpt 3}

Teacher : Ok. So (2.0) Ssstt! Helo? (3.0). Today, we are going to discuss what we have studied yesterday, eh:: last week, and before, and before, and before (2.0).

Ok, now, uhh, how did you go to school today? Huh? By? By motorcycle? So, how do you say "saya pergi ke sekolah dengan motor tadi pagi?" ("I went to school with motorcycle last morning")

Student : I'm go:: (1.0) I'm (3.0)

Student : $\square$ I go to school (2.0) I go to the school with motorcycle.

In excerpt 3, the teacher asked the students what they already studied in the last meeting. They were discussing the material first before the class was started. The teacher asked the students to translate the sentence into English, "how do you say 'saya pergi ke sekolah dengan motor tadi pagi?"' When the student tried to answer the question in the next turn, he was repeating the word "I'm go (1.0) I'm (3.0)", and cuts-off for three seconds. But after he got the answer, he immediately repaired his utterance to make the message was conveyed well to the interlocutor by saying "I go to school (2.0) I go to the school with motorcycle". In the student's statement, he realized that there was a trouble source in terms of his grammar that needed to be corrected. Therefore, he initiated to repair his utterance by repeating his statement.

In accordance with Schegloff et al. (1977) theory, the excerpt showed how self-initiated self-repair (SISR) used by the student in the conversation. According to them, SISR takes the form of initiation with a non-lexical initiator, followed by the repairing segment. To repair the errors in the conversation, language users repeat words to achieve communication goals.

\section{E. Self-Initiated Other-Repair (SIOR)}

Self-initiated other-repair (SIOR) is the least type of repair strategy used by EFL students. This type refers to the situation when the initiation of repair is given by the recipient, while the speaker does the repair completion (Schegloff et al., 1977). This strategy emerged 24 occurrences $(31.2 \%)$. The following excerpt is the sample of SIOR.

\section{Excerpt 4}

Student : $\square$ 'Was' itu kalau dibalik jadi 'saw'?

(Does 'was' in reverse become 'saw'?)

Teacher : Huh:: Beda lagi, it's different.

(Huh:: it's different, it's different)

Student : $\square$ 'Was' itu untuk apa?

('Was' is for what?)

Teacher : For 'is'
In excerpt 4 , the participants were discussing the past tense form. The student in the conversation initiated asking the teacher if the word 'was' was exchanged, would it become "saw." The teacher answered the question by saying, "it's different." After the student got the answer, he thought that he needed more explanation for the previous turn. Therefore, the student initiated to ask another question to get a repair by saying, "was' itu untuk apa?" ("was' is for what?). Then, the teacher repaired the trouble source by answering "for 'is."

The following excerpt showed the speaker acted as the trouble maker, and he would be the one who initiated the repair. However, the person who completed the repair was the interlocutor. It is called as self-initiated other-repair (SIOR) (Schegloff et al., 1977).

\section{F. The Techniques of Repair Initiation}

Besides the types of repair strategies, this study also investigated techniques of repair initiation. The theory based on the framework proposed by Finegan (2008). In the analysis, there are only three techniques used. However, another technique was found, which is giving a possible understanding toward the trouble source. The following Table II shows the result.

TABLE II. THE TECHNIQUES OF REPAIR INITIATION

\begin{tabular}{|c|c|c|c|}
\hline No. & Techniques of Repair Initiation & Frequency & Percentage \\
\hline 1 & Asking question toward the problem & 31 & $50.0 \%$ \\
\hline 2 & $\begin{array}{c}\text { Repeat part of the utterance to be } \\
\text { repaired }\end{array}$ & 13 & $21.0 \%$ \\
\hline 3 & Use particle and expression 'uhh' & 2 & $3.2 \%$ \\
\hline 4 & Abruptly stop speaking & - & - \\
\hline 5 & $\begin{array}{c}\text { Other (giving possible understanding } \\
\text { toward the trouble source) }\end{array}$ & 16 & $25.8 \%$ \\
\hline \multicolumn{2}{|c|}{ Total } & $\mathbf{6 2}$ & $\mathbf{1 0 0 \%}$ \\
\hline
\end{tabular}

The Table II above shows the most-frequently technique is asking question toward the problem. The explanation for each technique is discussed below.

\section{Asking Question}

Asking questions toward the problem is the most dominant one in the conversation among students and teachers. It reached 31 occurrences $(50.0 \%)$ out of 62 . It means that this technique used almost in half of the discussion. This technique appears either the speakers or the recipients ask a question to the interlocutor for repairing the trouble source. In the analysis, asking question technique appeared in both OISR and SIOR strategy. The explanations are shown below.

\section{Asking question in OISR}

In the conversation, asking question occurred in otherinitiated self-repair. The participants used this technique to get a clarification for the trouble source. Therefore, when the recipient initiates the repair to the speaker by giving a question, the speaker will correct the trouble source. The following excerpt is the example of asking question toward the problem in other-initiated self-repair. 


\section{Excerpt 5}

Teacher : Yes. 'Saw,' do you find it, 'saw'? Yes, diagonal.

Student : It's easy!

Teacher : $\square$ Huh? Is it easy?

Student : Yes!

In excerpt 5, the students were doing an exercise in the form of a puzzle. One of the students thought that the task that was given by the teacher was too easy, then he said: "it's easy!". Hearing to the student's statement, the teacher initiated asking a question to the student by saying, "Huh? It's easy?" In the next turn, the student repaired for clarification on her statement to the teacher by answering, "Yes!" Finegan (2008) claims the technique of repair initiation above is asking question toward the problem. This technique begins with an interrogative word. Besides, when the participants find the trouble source in the conversation, they will actively offer a question to get more explanations or clarifications for proper understanding (Tiara, 2018).

\section{Asking question in SIOR}

Asking question toward the problem did not only occur in other-initiated self-repair, but it also appeared in self-initiated other-repair. In SIOR, the speaker used this technique to get an explanation and clarification toward the trouble source to the recipient. Excerpt 6 shows the example of SIOR in the conversation.

\section{Excerpt 6}

Student : Kenapa:: kenapa banyak yang bilang 'I had'?

(Why:: Why do many people say 'I had'?)

$\checkmark$ 'I had' itu 'aku benci'?

(Does 'I had' mean 'I hate'?)

Teacher : Itu 'hate'. Nah:: ini 'I had.'

(It's 'hate'. Nah:: this is 'I had')

In excerpt 6 , the student was wondering why other students said 'had'. Then, he initiated to ask the teacher for clarification what 'had' was by saying 'I had' itu 'aku benci'? (Does 'I had' mean 'I hate'?). The teacher, as the recipient, clarified that the word 'had' did not mean 'hate' by saying 'Itu 'hate.' Nah:: ini 'I had.' (It's 'hate.' Nah:: this is 'I had')".

As can be seen in excerpt 6, according to Finegan (2008) the student used asking question toward the problem technique because he wanted to get a repair by asking the teacher a question toward the trouble source. The technique was used to avoid misunderstanding between the teacher and the student.

\section{Giving Possible Understanding toward the Trouble Source}

Another technique was found in the conversation, which is giving possible understanding toward the trouble source. This technique is a combination of ' $\mathrm{Y}$ mean plus a possible understanding of prior turn' technique proposed by Schegloff et al. (1977) in their theory of techniques of repair initiation.
Based on the analysis, the occurrences of this technique occurred 16 (25.8\%). The excerpt 7 shows the example.

\section{Excerpt 7}

Teacher : Nahh:: saw (2.0). Saw is not just see, tapi uhh (2.0) meet.

Do you know meet?

Student1: Engga.

(No)

Student2: Daging?

(Meat?)

Teacher : $\square$ Bertemu, meet (write the word on the board).

In excerpt 7, the teacher and the student were talking about the vocabulary. The teacher said and asked what the translation of 'meet' in Indonesian. The student's 1 answer was he did not know what 'meet' was, but another student (student 2) said that the translation of 'meet' means that it was 'daging' (meat). However, the student's 2 statements caused the trouble source in which the answer was incorrect. In the next turn, the teacher immediately initiated and repaired the student's utterance by himself into the correct one by saying, "bertemu, meet."

In the conversation, the participants used other-initiated other-repair strategy. And the technique of repair initiation that was employed is giving possible understanding toward the trouble source because the teacher gave his understanding of the mistake to repair student's statement. It is called as giving possible understanding toward the trouble source (Schegloff et al., 1977).

\section{Repeat Part of the Utterance to be repaired}

Repeating part of the utterance appeared 13 occurrences $(21.0 \%)$ in the conversation. The participants used this technique of repair initiation. It is because they recognized their own mistakes and tried to repair it by repeating their utterance to get the correct answer, as can be seen in excerpt 8 below.

\section{Excerpt 8}

Teacher : Between, what is between?

Student : $\square$ Di antara (1.0) Di tengah-tengah!

( $\square$ Between (1.0) in the middle!)

In the example of the repeat part of the utterance above, the participants were talking about the preposition. When the teacher asked the students the Indonesian translation for the word "between" by asking "between, what is between?". The student tried to answer the question, but she recognized the trouble source in her utterance. Therefore, she had a role as the one who initiated and repaired her statement by herself by repeating "Di antara (1.0) di tengah-tengah!" because she wanted the interlocutor to understand her intended.

In excerpt 8 , the student used self-initiated self-repair strategy. According to Finegan (2008), repeat part of the utterance to be repaired technique is when repair initiation that appears in the same turn as the speaker talks. Also, Rieger (2000) states that repetition is the type of self-repair in which 
the repairable and repairing segments happen in the same turn, and the repair is performed by the initiator of the repairable.

\section{Use particle and expression ' $u h h$ '} $(3.2 \%)$.

The particle and expression of 'uhh' appeared only twice

\section{Excerpt 9}

Teacher : Which one is odd one?

Student : Kick

Teacher : $\square$ Kick, why?

Student : Karena dia nendang (1.0) yang lain mah - uhh(3.0) bagian tubuh, anatomi.

(Because he kicks (1.0) and the other - uhh - (3.0) is a part of body, anatomy)

According to Finegan (2008), this act is called a use particle and expression 'uhh' when there is a pause in the middle of the speaker's utterance. The participant used this expression because she wanted to give the best answer by explaining her statement carefully. Also, to make sure that the answer was correct, so the recipient could understand the message that she tried to convey.

\section{CONCLUSION}

Other-initiated self-repair (OISR) is the most frequently used repair strategy among the students at the beginner level. Then, the speaker repairs his/her utterances for the speaker in the next turn. Therefore, the conversation can be understandable with each other. In the conversation among the students and their teacher, this OISR appeared because the students produced the trouble source more which affected to the teacher to initiate asking for the repair. The trouble source was affected by the students' level of English competence that was still at the beginner.

The finding also revealed that asking question toward the problem gained 31 occurrences $(50.0 \%)$. The teacher mostly initiated asking for clarification or further explanation to the students' statement. However, when the students tried to repair the repaired segments, they were sometimes confused. Their confusion caused repeating some part of the utterances, or cutoff for more than a second during conveying the message because the lack of knowledge that they had. Although, the present study showed that Elementary EFL students still could answer the question by switching from English into Indonesian or combining both languages. It depended on their knowledge of English toward the topic in the discussion, hence, the use of other-initiated self-repair (OISR) in the conversation.

\section{REFERENCES}

Cameron, L. (2001). Teaching languages to young learners. New York, NY: Cambridge University Press.

Chalak, A., \& Karimi, M. (2017). Analysis of turn taking and repair strategies among male and female Iranian intermediate EFL learners. Journal of Applied Linguistics and Language Research, 4(2), 1-9. Retrieved from http://jallr.com/index.php/JALLR/article/view/508

Cho, E. H., \& Larke, P. (2010) Repair strategies usage of primary elementary ESL students: Implication for ESL teachers. The Electronic Journal for English as a Second Language, 14(3), 1-18.

Finegan, E. (2008). Language: Its structure and use ( $5^{\text {th }}$ edn.). USA: Thomson Wadsworth

Jefferson, G. (2004). Glosarry of transcript symbols with an introduction. In G H. Learner (Ed), Conversation analysis: Studies from the first generation (pp. 13-31). Amsterdam: John Benjamins.

Khodadady, E. \& Alifathabadi, J. (2014). Repair in EFL talk: A case of Iranian intermediate and advanced EFL learners. Theory and Practice in Language Studies, 4(10), 2129-2137. doi: 10.4304/tpls.4.10.2129-2137

Liddicoat, A. J. (2007). An introduction to conversation analysis. London: Athenaeum Press Ltd

Mazeland, H. (2006). Conversation analysis. Encyclopedia of Language \& Linguistics, 3, 153-163. doi: 10.1016/B0-08-044854-2/00314-X

Meredith, J. \& Stokoe, E. (2014). Repair: Comparing facebook 'chat' with spoken interaction. Discourse \& Communication, 8(2), 181-207. doi: $10.1177 / 1750481313510815$

Ohtake, Y., Yanagihara, M., Nakaya, A., Takahashi, S., Sato, E., \& Tanaka, M. (2005). Repair strategies used by elementary-age beginning communicators with autism: A preliminary descriptive study. Focus on Autism and Other Developmental Disabilities, 20(3), 158-168. doi: $10.1177 / 10883576050200030401$

Ohtake, Y., Wehmeyer, L. M., Nakaya, A., Takahashi, S., \& Yanagihara, M. (2011). Repair strategies used by verbal students with autism during free play. Focus on Autism and Other Developmental Disabilities, 26(1), 314. doi: 10.1177/1088357610396079

Paltridge, B. (2006). Discourse analysis: An introduction. London: Routledge.

Rabab'ah, G. (2013). Strategies of repair in EFL learner's oral discourse. English Language Teaching, 6(6), 123-131. doi: 10.5539/elt.v6n6p123

Rieger, C., L. (2000). Self-repair strategies of English-German bilinguals in informal conversations: The role of language, gender and proficiency (Unpublished doctoral dissertation). University of Alberta.

Schegloff, E. A. (1973). Opening up closings. Semiotica, 8(4), 289-327. doi 10.1515/semi.1973.8.4.289

Schegloff, E. A., Jefferson, G., \& Sacks, H. (1977). The preferences for selfcorrection in the organization of repair in conversation. Language, 53(2), 361-382. doi: $10.2307 / 413107$

Tiara, A. (2018). Repair strategies in online chat: A conversation analysis (Unpublished bachelor's thesis). Universitas Pendidikan Indonesia.

Wray, A. \& Bloomer, A. (2006). Projects in linguistics a practical guide to researching language ( $2^{\text {nd }}$ edn.). London: Hodder Education Publishers. 